\section{'Novablue', a Seed-propagated Lowbush Blueberry Family}

\author{
Andrew Raymond Jamieson ${ }^{1,2}$ \\ Agriculture and Agri-Food Canada, Atlantic Food and Horticulture \\ Research Centre, 32 Main St., Kentville, Nova Scotia, B4N 1J5, Canada
}

Additional index words. Vaccinium angustifolium, fruit breeding, cultivar, seed

\begin{abstract}
'Novablue' is the first seed-propagated lowbush blueberry (Vaccinium angustifolium Aiton) introduced from the Atlantic Food and Horticulture Research Center, Agriculture and Agri-Food Canada, Kentville, Nova Scotia. Previously, six clonally propagated cultivars have been released from this program (Hall et al., 1988). Plants propagated from cuttings can be difficult to establish in the field (Jamieson and Nickerson, 2003). The advantages of seed propagation over clonal propagation include a lower cost of plants, better establishment in the field with more rhizome formation, and the lack of requirement for planting a second cultivar for cross-pollination. Previous studies have shown that seed-propagated lowbush blueberries are typically low yielding (Aalders and Hall, 1975; Aalders et al., 1979; Hall, 1983), but these same studies suggest that high-yielding populations can be developed.
\end{abstract}

\section{Origin}

'Novablue' was chosen as a top performer among 42 Kentville Blueberry Families (KBFs) grown at the Sheffield Farm, Sheffield Mills, Nova Scotia (Jamieson, 2008). 'Novablue', tested as KBF-7, is a population of plants grown from 'Fundy' pollenized by 'Brunswick'. 'Brunswick' is a tall-stemmed, very flavorful, large-fruited native selection found in New Brunswick, Canada, and introduced in 1977 (Aalders et al., 1977). 'Fundy' is a more recent cultivar noted for its consistently high yields of large, firm, light blue fruit (Hall et al., 1988). Both cultivars are considered to be pure $V$. angustifolium. 'Novablue' was introduced and briefly described in 2006 (Clark and Finn, 2006).

\section{Description and Performance}

'Novablue' was initially tested in plots established in 1990 and harvested from 1992

Received for publication 23 Dec. 2007. Accepted for publication 26 May 2008

Atlantic Food and Horticulture Research Centre Contribution no. 2347.

I thank Avard Brydon for the initial technical responsibilities followed by Pansy Rand and Michael Graves. I thank Dr. John DeLong and Dr. Nancy Nickerson for reviewing the manuscript. ${ }^{1}$ Fruit Breeder.

${ }^{2}$ To whom reprint requests should be addressed; e-mail jamiesona@agr.gc.ca to 2000 (Jamieson, 2008). In addition to the initial trial, plants of 'Novablue' were grown and compared with parental cultivar 'Fundy' in a trial set out on 9 June 1998 at the Sheffield Farm.

This second trial was established with similar-sized plants grown from seed of 'Novablue' or from softwood cuttings of 'Fundy'. The rhizome growth of 'Novablue' and 'Fundy' was compared in September of the third growing season. Most plants of 'Fundy' had produced no new shoots from rhizomes, but 'Novablue' plants had a mean of 3.1 shoots (Table 1 ). In the same plots in 2004, stems and flowers were evaluated. Stems of 'Novablue' were shorter than those of 'Fundy' and generally unbranched (Table 1). Unbranched stems are more amenable to mechanical harvesting. 'Novablue' had fewer flower buds per stem but a similar number of flowers per bud. The flowers of 'Novablue' are similar to 'Fundy' in size but shorter than those of 'Brunswick', which was growing in an adjacent plot (Table 2). 'Novablue' and its parents have white flowers; however, redpurple stripes or blotches are present in some years if temperatures are low (near $0{ }^{\circ} \mathrm{C}$ ) during flower development. The leaves of 'Novablue' are ovate to ovate-elliptic and the size range encompasses the smaller-leaved 'Fundy' and the larger 'Brunswick' (data not shown). Stem color, as observed in June, is typically green for 'Fundy', red for 'Brunswick', and either red or green for 'Novablue'.

In the original trial in which 'Novablue' (KBF-7) was chosen for release, it was in the top group for yield over six harvest seasons
${ }^{\mathrm{z}}$ Mean \pm SD (number of observations).

${ }^{\mathrm{z}}$ Based on measurements of 15 flowers.
(Jamieson, 2008). The mean yield was $5.6 \mathrm{t} \cdot \mathrm{ha}^{-1}$ and the maximum was $11.2 \mathrm{t} \cdot \mathrm{ha}^{-1}$ in 1998 . Because these plots were not always ideally managed for maximum production-they were on imperfectly drained soil, weeds provided competition in the later years, and natural pollinators were relied on-it is expected that yields in excess of the mean can be attained biennially in a commercial setting. In the same trial, the berries of 'Novablue' had a mean weight of $0.57 \mathrm{~g}$, larger than unselected blueberries produced commercially ( 0.2 to $0.4 \mathrm{~g})$ but a bit smaller than 'Fundy' and 'Brunswick' (Hall et al., 1988). 'Novablue' fruit are firm with an attractive, light powdery blue color similar to 'Fundy' (Fig. 1).

\section{Seed Production}

Plants of 'Fundy' and 'Brunswick' were established in 1998 in field soil under a tunnel house structure $(4.9 \times 29.3 \mathrm{~m})$ to investigate seed production. Initially, the structure was divided into four sections to produce four hybrid seed populations, but it was subsequently converted to produce only 'Fundy' $x$ 'Brunswick'. The 'Novablue' section contained five rows planted $1 \mathrm{~m}$ apart; the central row was 'Brunswick' and the four outer rows were 'Fundy'. Before flowering, the tunnel was covered with $50 \%$ shadecloth, which forms a barrier to bees. One colony of bumblebees (Koppert Canada Ltd., Scarborough, Canada) was placed in the tunnel at $\approx 10 \%$ bloom to ensure pollination. The shadecloth was left in place until after harvest to protect the crop from predators. In 1999, the seed content of eleven 250-g samples of 'Fundy' was examined. Seed was extracted in a blender, dried on a laboratory bench, and then screened by passing through sieves (Aalders et al., 1980). Seeds passing through the $600-\mu \mathrm{m}$ (No. 30) sieve were classed as small and those collected on this sieve were classed as large. Large seeds are known to have higher germination rates (Aalders and Hall, 1979). The mean weight of seeds per gram of fresh fruit was $6.41 \mathrm{mg}(\mathrm{SD}=0.58)$. Of these, $2.70 \mathrm{mg}(\mathrm{sD}=0.17)$ were large

Table 1. Rhizome shoot counts and stem measurements of 'Novablue' and 'Fundy'.

\begin{tabular}{lrr}
\hline Variate & \multicolumn{1}{c}{ Novablue } & \multicolumn{1}{c}{ Fundy } \\
\hline No. shoots from rhizomes & $3.1 \pm 3.20(41)^{\mathrm{z}}$ & $0.1 \pm 0.59(36)$ \\
Stem length (cm) & $11.3 \pm 3.62(25)$ & $19.7 \pm 6.22(25)$ \\
No. stem branches & $0.1 \pm 0.40(25)$ & $1.6 \pm 1.71(25)$ \\
No. flower buds & $2.1 \pm 1.58(25)$ & $4.9 \pm 2.98(25)$ \\
No. flowers per bud & $5.2 \pm 1.82(46)$ & $5.4 \pm 1.81(105)$ \\
\hline
\end{tabular}

Table 2. Mean flower size of 'Novablue', 'Fundy', and 'Brunswick'.

\begin{tabular}{lccc}
\hline Cultivar & $\begin{array}{c}\text { Flower } \\
\text { width }^{\mathrm{z}}(\mathrm{mm} \pm \mathrm{SD})\end{array}$ & $\begin{array}{c}\text { Flower } \\
\text { length }^{\mathrm{z}}(\mathrm{mm} \pm \mathrm{SD})\end{array}$ & $\begin{array}{c}\text { Inside opening } \\
\text { diam. }^{\mathrm{z}}(\mathrm{mm} \pm \mathrm{SD})\end{array}$ \\
\hline Novablue & $4.8 \pm 0.32$ & $7.4 \pm 0.33$ & $3.1 \pm 0.27$ \\
Fundy & $5.0 \pm 0.29$ & $7.5 \pm 0.32$ & $3.4 \pm 0.23$ \\
Brunswick & $5.0 \pm 0.21$ & $8.0 \pm 0.28$ & $3.4 \pm 0.20$ \\
\hline
\end{tabular}




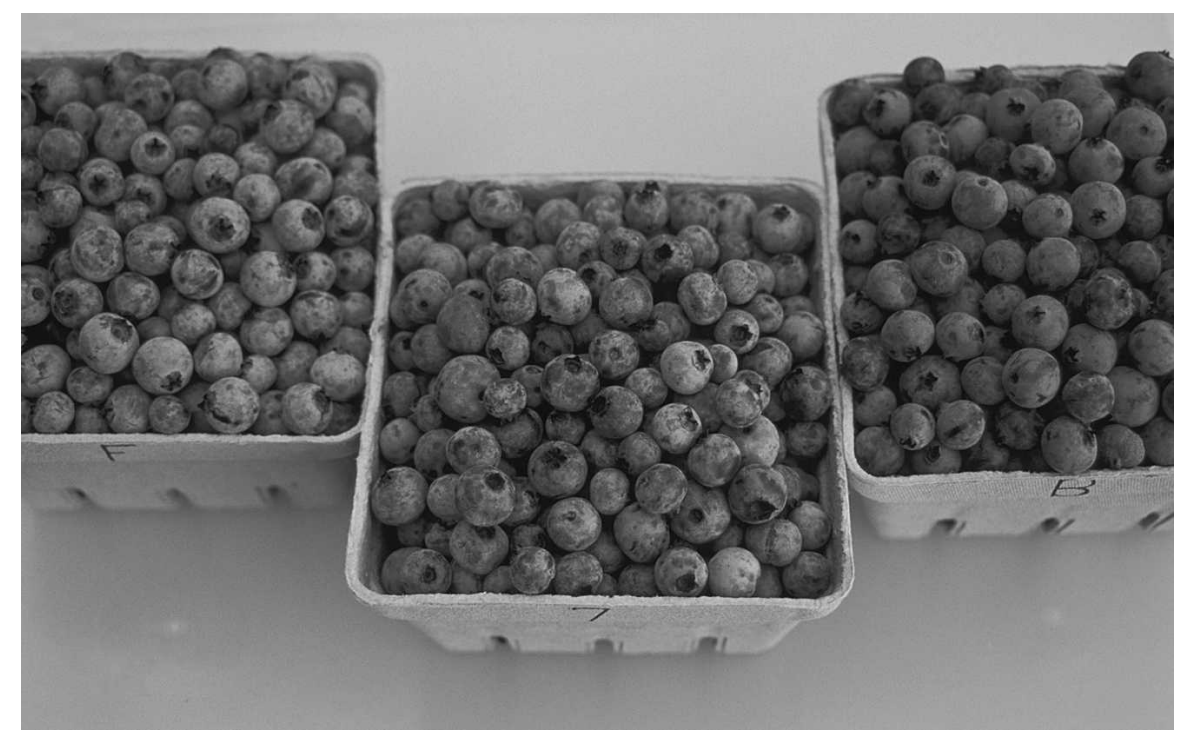

Fig. 1. A pint of 'Fundy' (left), 'Novablue' (center), and 'Brunswick' (right).

seeds. Average individual seed weight was $0.256 \mathrm{mg}(\mathrm{SD}=0.01)$ for large and $0.101 \mathrm{mg}$ $(\mathrm{SD}=0.01)$ for small seeds. In this study, we calculated that there would be 10,500 large seeds and 35,700 small seeds per kilogram of fresh berries. One gram of large seed contained $\approx 3900$ seeds. Germination of large 'Fundy' seed exceeds 70\% (Aalders et al., 1980) and a commercial nursery achieved $79 \%$ germination from 'Novablue' seeds produced in 1999. In the seed production tunnel, yields of fruit increased from 0.25 $\mathrm{kg} \cdot \mathrm{m}^{-2}$ in 2003 to $0.45 \mathrm{~kg} \cdot \mathrm{m}^{-2}$ in 2007. Assuming a berry yield biennially of 0.5 $\mathrm{kg} \cdot \mathrm{m}^{-2}$ from a mature seed production plot, will be provided by the breeder on request. 'Fundy' and 'Brunswick' are present in the National Clonal Germplasm Repository at Corvallis, OR.

\section{Literature Cited}

Aalders, L.E. and I.V. Hall. 1975. A study of variation in fruit yield and related characteristics in two diallels of the lowbush blueberry, Vaccinium angustifolium Ait. Can. J. Genet. Cytol. 17:401-404.

Aalders, L.E. and I.V. Hall. 1979. Germination of lowbush blueberry seeds as affected by sizing. planting cover, storage, and pelleting. Can. J. Plant Sci. 59:527-530.

Aalders, L.E., I.V. Hall, and A.C. Brydon. 1979. A comparison of fruit yields of lowbush blueberry clonal lines and related seedling progenies. Can. J. Plant Sci. 59:875-877.

Aalders, L.E., I.V. Hall, and A.C. Brydon. 1980. Seed production and germination in four lowbush blueberry clones. HortScience 15:587588

Aalders, L.E., I.V. Hall, and L.P. Jackson. 1977. Brunswick lowbush blueberry. Can. J. Plant Sci. 57:301.

and a germination rate of $75 \%$, a seed production area of $\approx 450 \mathrm{~m}^{2}$ would be required to annually produce enough large seed for a million 'Novablue' plants. If seed production were isolated from other wild or cultivated blueberries, then a protective structure would not be required.

\section{Availability}

'Novablue' is introduced without plant variety protection. Seed samples of 'Novablue' may be requested from the breeder until a commercial source is available. Sources of the parental plants, 'Fundy' and 'Brunswick',

Clark, J.R. and C.E. Finn. 2006. Register of new fruit and nut cultivars: List 43. HortScience 41:1101-1133.

Hall, I.V. 1983. Genetic improvement of the lowbush blueberry, Vaccinium angustifolium. Can. J. Plant Sci. 63:1091-1092.

Hall, I.V., A.R. Jamieson, and A.C. Brydon. 1988. Cumberland and Fundy lowbush blueberries. Can. J. Plant Sci. 68:553-555.

Jamieson, A.R. 2008. Developing seed-propagated lowbush blueberry families. J HortScience 43:1686-1689.

Jamieson, A.R. and N.L. Nickerson. 2003 Field performance of the lowbush blueberry propagated by seed, stem cuttings and micropropagation. Acta Hort. 626:423-428. 